\title{
Pengujian Model Pengaktivasian Norma Personal dalam Perspektif Pemasaran Sosial
}

\author{
RAHAB $^{1}$, AGNES FITRIA WIDIYANTO² \\ ${ }^{1}$ Fakultas Ekonomi dan Bisnis Universitas Jenderal Soedirman, Jln. HR. Boenyamin 708 Purwokerto 53122. \\ 2 Jurusan Kesehatan Masyarakat, Fakultas Ilmu Kesehatan, Universitas Jenderal Soedirman, Purwokerto 53123. \\ email: ${ }^{1}$ rahab_inc@yahoo.co.id, 2 agnesFH@unsoed.ac.id
}

\begin{abstract}
The success of trash bank program to reduce negative impact of waste determined by community participation. Personal norm activation plays an important role for stimulating individual motivation to engage on trash bank program. The purpose of study is to examine antecedents and consequences of personal norms in pro environmental behavior context. Research location in Banyumas regency area. Data mining are done through surveys by purposive sampling technique. The respondents are trash bank's customers. Data were analyzed using structural equation modeling (SEM). The results showed that ascription of responsibility, subjective norm, and ability significantly effect on activation process of personal norms. Furthermore, personal norms and ability significantly positive effect on community participation on trash bank.
\end{abstract}

Key words: norm, social marketing, subjective, participation, trash bank, civic.

\begin{abstract}
Abstrak. Keberhasilan program bank sampah untuk mengurangi dampak negatif dari sampah ditentukan oleh partisipasi masyarakat. Pengaktivasian norma personal berperan penting dalam mendorong motivasi untuk terlibat pada bank sampah. Tujuan penelitian ini adalah menguji anteseden dan konsekuensi dari norma personal dalam konteks perilaku pro lingkungan. Lokasi Penelitian di wilayah Kabupaten Banyumas. Penggalian data dilakukan melalui survei dengan teknik penyampelan purposive sampling. Responden penelitian ini adalah nasabah bank sampah. Data dianalisis dengan menggunakan structural equation modeling. Hasil penelitian menunjukkan bahwa anggapan tanggung jawab, norma subjektif, dan kemampuan berpengaruh signifikan pada proses pengaktivasian norma personal. Lebih lanjut, norma personal dan kemampuan memiliki pengaruh positif pada partisipasi masyarakat pada program bank sampah.
\end{abstract}

Kata Kunci: norma, pemasaran sosial, subjektif, bank sampah, masyarakat.

\section{Pendahuluan}

Peningkatan produksi sampah rumah tangga merupakan salah satu efek dari pertumbuhan populasi, munculnya standar hidup, urbanisasi dan pembangunan yang cepat (Mahar et al., 2007). Sampah rumah tangga secara umum didefinisikan sebagai sampah yang diproduksi oleh aktivitas seharihari rumah tangga (Mbande, 2003). Sampah rumah tangga adalah salah satu sumber utama sampah padat perkotaan yang membutuhkan pengelolaan secara terintegrasi bagi semua pihak (Karak et al., 2012). Lehman dan Geller (2004) menyatakan bahwa makin banyaknya produk yang diproduksi oleh manusia dan banyaknya sampah yang dihasilkan dari konsumsi manusia akan mendorong makin meningkatkan krisis lingkungan dan ancaman serius bagi lingkungan dan ekosistem di dalamnya. Secara umum, pengeloaan sampah dihadapkan dengan berbagai tantangan meliputi peningkatan jumlah dan kompleksitas jenis sampah. Samsudin dan Don (2013) menyatakan bahwa sampah sudah diakui secara umum memiliki dampak yang berbahaya bagi lingkungan dan ekosistem didalamnya.

Masalah tersebut mendorong munculnya bahaya bagi lingkungan seperti peningkatan infeksi, penurunan kualitas lingkungan, polusi tanah dan air, emisi rumah kaca dan dampak negatif lainnya pada kualitas hidup manusia (Miller, 2000). Masalah tersebut umumnya ditemukan pada negara-negara berkembang

Received: 14 Januari 2015, Revision: 18 Mei 2015, Accepted: 26 Mei 2015

Print ISSN: 0215-8175; Online ISSN: 2303-2499. Copyright@2015. Published by Pusat Penerbitan Universitas (P2U) LPPM Unisba Terakreditasi SK Kemendikbud, No.040/P/2014, berlaku 18-02-2014 s.d 18-02-2019 
karena operasi pengumpulan sampah tidak terjadi pada semua tempat dan tidak mampu menampung semua sampah rumah tangga yang ada di perkotaan. Salah satu solusi untuk membantu menyelesaikan permasalah sampah yaitu dengan cara mendorong rumah tangga untuk berpartisipasi pada bank sampah. Bank sampah merupakan lembaga yang didirikan dalam rangka mengelola sampah rumah tangga. Program bank sampah merupakan gerakan nasional yang dipromosikan oleh Kementrian Lingkungan Hidup Republik Indonesia. Program bank sampah tidak hanya bermanfaat dalam masalah isu lingkungan tetapi juga dapat menjadi media untuk pemberdayaan masyarakat dalam aspek ekonomi dengan melakukan pendarulang sampah menjadi komoditas ekonomi yang bernilai tinggi seperti pupuk, kerajinan dan pemakaian kembali barang yang telah digunakan.

Lebih lanjut, kesuksesan program bank sampah tergantung pada partisipasi masyarakat khususnya rumah tangga. Dalam perspektif pemasaran sosial, faktor psikologi dan keperilakuan mempengaruhi motivasi masyarakat untuk terlibat pada program penanganan sampah rumah tangga melalui bank sampah. Faktor psikologi dan keperilakuan merupakan informasi penting dalam menyusun strategi intervensi pemasaran sosial bagi pengelola bank sampah (Kofoworola, 2007; Rahardyan et al., 2004; Wilkinson, 2007). Terungkapnya faktor yang memberikan kontribusi penting dalam mendorong motivasi individu dapat menjadi bahan bagi para pemasar sosial untuk melakukan segmentasi target sasaran. Kebutuhan untuk menguji dan melakukan penelitian berbasis teori untuk memahami mekanisme keterlibatan masyarakat pada program bank sampah merupakan salah satu upaya untuk mendapatkan justifikasi teoritis yang bermanfaat dalam mengimplementasikan konsep-konsep pemasaran komersial pada konteks rekayasa sosial. Beberapa teori perubahan perilaku telah banyak diaplikasikan untuk menjelaskan faktor-faktor yang mempengaruhi motivasi keterlibatan meliputi: Schwartz's Norm Activation model (Van Liere dan Dunlap, 1978), the theory of reasoned action (Ajzen dan Fishbein, 1980), dan the theory of planned behaviour (Ajzen, 1991). Teori-teori tersebut banyak digunakan dalam kajian pemasaran sosial dalam menjelaskan perubahan perilaku individu.

Beberapa literatur yang meneliti mengenai tindakan konservasi lingkungan pada dimensi privat atau individu telah menyelidiki mengenai faktor-faktor penentu dari praktek pengelolaan sampah untuk perlindungan lingkungan oleh individu misalnya, adopsi keranjang takakura, teknologi komposting dan pendaur ulang sampah plastik (Armstrong, 2014; Knowler dan Bradshaw, 2007; Soule, Tegene, dan Wiebe, 2000). Selain itu, terdapat beberapa penelitian yang telah mengkaji mengenai faktor penentu dari tindakan konservasi pada dimensi publik seperti konservasi kewarganegaraan atau advokasi (Stern, 2000).

Perilaku individu yang berkaitan dengan konservasi lingkungan selalu dihadapkan pada dilema sosial. Dilema sosial adalah situasi yang menggambarkan adanya persaingan antara kepentingan kolektif dengan kepentingan individu. Dalam dilema sosial, ketika individu memrioritaskan kepentingan personal maka akan berperilaku atas dasar pertimbangan rasional dibandingkan pertimbangan moral (Dawes dan Messick, 2000; Dawes, 1980). Pembuatan keputusan yang mengarah pada upaya kelestarian lingkungan sering dicirikan sebagai dilema sosial (Nordlund dan Garvill, 2003; Thøgersen, 1996). Memecahkan masalah yang berkaitan dengan dilema sosial seperti masalah sampah membutuhkan keterlibatan masyarakat sebagai rangkaian proses penguatan wacana mengenai permasalahan lingkungan, musyawarah dan pengambilan keputusan. Fagotto dan Fung (2009) mendefinisikan keterlibatan masyarakat sebagai langkah membuat keputusan publik dan mengambil tindakan kolektif melalui proses yang melibatkan diskusi, penalaran, dan partisipasi warga negara bukan melalui implementasi kewenangan, keahlian, status, kekuatan politik, atau bentuk-bentuk kekuasaan lainnya.

Para cendekiawan dan praktisi yang selama ini memusatkan perhatianya pada masalah sampah mengakui bahwa warga harus terlibat dalam masalah sampah melalui pendekatan kolektif (Brooks, Franzen, Holmes, Grote, dan Mulder, 2006; Morton dan Brown, 2011). Namun demikian, tingkat keterlibatan masyarakat dalam kaitannya dengan penanganan sampah dapat menjadi semakin rendah apabila konsep dan mekanisme bank sampah tidak jelas. Penelitian mengenai kewajiban personal dari rumah tangga untuk terlibat dalam tindakan konservasi lingkungan melalui penanganan sampah menemukan bahwa lebih dari 80 $\%$ dari responden penelitian melaporkan 
adanya perasaan kewajiban personal untuk mengadopsi praktek-praktek penanganan sampah dari sumbernya, sementara kurang dari 50\% melaporkan bahwa mereka merasa memiliki kewajiban personal untuk berbicara dengan orang lain tentang praktek pengelolaan sampah yang dilakukannya (Davenport et al., 2013).

Minimnya keterlibatan masyarakat pada penanganan sampah menjadi isu yang penting untuk mengatasi masalah pencemaran lingkungan melalui pendekatan tindakan kolektif masyarakat. Selain itu, beberapa penelitian telah menunjukkan bahwa perilaku konservasi dipengaruhi oleh tekanan sosial yang dirasakan atau normanorma perilaku sosial (Bamberg et al., 2007; Klockner dan Blöbaum, 2010). Untuk mendorong keterlibatan masyarakat perlu adanya intervensi dengan melibatkan individu dalam suatu proses dialog, mengembangkan norma-norma sosial perilaku konservasi dan menginspirasi tindakan kolektif dengan didasarkan pada pemahaman tentang faktorfaktor penentu perilaku publik.

Beberapa penelitian terdahulu menunjukkan bahwa individu dengan pendapatan yang lebih tinggi dan tingkat pendidikan formal yang lebih tinggi lebih memungkinkan untuk terlibat pada aktivitas konservasi lingkungan (misalnya, partisipasi dalam organisasi lingkungan) (Larson dan Lach, 2010; Manzo dan Weinstein, 1987; Smith, 1994). Faktor sosio-demografis lainnya seperti umur, jenis kelamin, kepemilikan rumah, dan panjang dan lokasi tempat tinggal telah banyak dikaitkan dengan kajian mengenai keterlibatan masyarakat pada gerakan konservasi lingkungan (Koehler dan Koontz, 2008; Larson dan Lach, 2010; Martinez dan McMullin, 2004). Namun demikian, hanya beberapa penelitian yang difokuskan pada faktor-faktor psiko-sosial sebagai penentu keterlibatan masyarakat pada program konservasi lingkungan. Larson dan Lach (2010) melaporkan bahwa individu-individu yang terlibat program-program konservasi lingkungan memiliki pandangan pro-ekologi yang lebih kuat dan lebih mendukung pada isu perlindungan lingkungan.

Dalam penelitian lain, perasaan keberhasilan dan keyakinan tentang efektivitas konservasi lingkungan dipengaruhi kesukarelaan dalam suatu organisasi lingkungan (Martinez dan McMullin, 2004). Kesadaran individu tentang masalah lingkungan dan tanggung jawab personal untuk melindungi lingkungan juga telah dilaporkan sebagai prediktor niat positif warga negara untuk terlibat pada gerakan pro lingkungan (misalnya, bicara kepada orang lain tentang kebersihan lingkungan) (Story dan Forsyth, 2008). Tujuan penulisan ini adalah untuk mengeksplorasi faktor-faktor psiko-sosial yang mempengaruhi keterlibatan masyarakat pada bank sampah. Mengingat bahwa sebagian besar perilaku konservasi merupakan keputusan moral (Harland et al., 2007; Stern, 2000; Thøgersen, 1996), maka penelitian ini menggunakan teori aktivasi norma (Schwartz, 1977) sebagai dasar untuk menganalisis faktor-faktor penentu dari keterlibatan masyarakat pada bank sampah.

\section{Pengaruh Norma Personal pada Partisipasi Masyarakat}

Teori moral (moral theory) menganggap bahwa perilaku pro-lingkungan sebagai pilihan situasi moral ketika tindakan individu memiliki konsekuensi untuk kesejahteraan orang lain (misalnya, Harland, Taats, dan Wilke, 2007; Nordlund dan Garvill, 2003; Pradhananga, 2014). Berbeda dengan teoriteori pilihan rasional, teori moral menunjukkan bahwa perilaku, terutama perilaku prososial (misalnya, membantu orang lain) atau perilaku pro-lingkungan (misalnya, membuang sampah pada tempatnya), dipengaruhi oleh perasaan kewajiban moral atau norma personal. Menurut teori aktivasi norma (norm activation theory/ NAT), intensitas kewajiban personal terjadi ketika seseorang merasa untuk mengambil tindakan perilaku yang berpengaruh pada lingkungan sekitar (Schwartz, 1977). Demikian pula, norma personal merupakan pendorong utama perilaku dalam value-belief-norm theory (VBN) (Stern, 2000). Dalam sebuah penelitian perilaku pro-lingkungan (misalnya, menandatangani petisi untuk mendukung undang-undang yang pro lingkungan hidup), Stern, Dietz, Abel, Guagnano dan Kalof (1999) melaporkan bahwa pengaruh norma personal signifikan secara statistik untuk bertindak atas pro-lingkungan. Demikian pula, dalam penelitian tingkah laku pro lingkungan kolektif yang lain (misalnya, menyumbangkan uang untuk sebuah organisasi lingkungan), norma personal untuk melindungi lingkungan adalah prediktor signifikan dari niat perilaku prolingkungan. Dalam sebuah penelitian pada responden mahasiswa di Belanda, individu yang merasa mempunyai kewajiban personal untuk menjadi relawan lebih mungkin untuk menjadi sukarelawan untuk organisasi 
lingkungan (Harland et al., 2007). Dalam aplikasi lain dari VBN, Johansson, Rahm dan Gyllin (2013) melaporkan bahwa pemilik tanah yang telah berpartisipasi dalam program konservasi lingkungan merasakan kewajiban personal yang lebih besar untuk berpartisipasi dalam program konservasi keanekaragaman hayati daripada pemilik tanah yang tidak berpartisipasi.

\section{Aktivator Norma Personal}

Norma personal diaktifkan oleh struktur kognitif nilai-nilai dan keyakinan seseorang (Schwartz, 1977). NAT dan VBN menyatakan bahwa norma-norma personal diaktifkan ketika seorang individu menyadari konsekuensi yang merugikan dari kondisi lingkungan (kesadaran konsekuensi) dan menganggap tanggung jawab terhadap para pelaku untuk mengurangi ancaman konsekuensi mereka yang merugikan (anggapan tanggung jawab) (Stern, 2000). Dalam sebuah penerapan Schwartz mengenai NAT, Gärling et al., (2003) menunjukkan pengaruh kesadaran konsekuensi dan anggapan tanggung jawab pada norma-norma personal untuk melindungi lingkungan, yang pada gilirannya memprediksi niat perilaku pro-lingkungan (misalnya, kontribusi uang untuk sebuah organisasi lingkungan). Demikian pula, Stern dan rekan-rekan kerjanya Stern et al., 1999; Stern dan Dietz, 1994; Stern, 2000) juga menunjukkan kemampuan prediksi dari kesadaran konsekuensi dan anggapan tanggung jawab. Keyakinan mengenai konsekuensi pada gilirannya dipengaruhi oleh tiga set nilai-nilai yang mendasari yang tidak berubah: egoistik, altruistik dan nilai biosphorik.

Untuk pemasar sosial/ pengurus program bank sampah, lebih efektif dan efisien untuk mengembangkan intervensi keterlibatan masyarakat yang berfokus pada faktor-faktor penentu perilaku yang lebih menonjol. Keunggulan dan stabilitas dari berbagai aktivator telah menjadi salah satu fokus penelitian normatif. Penelitian normatif menunjukkan bahwa intervensi berfokus hanya pada informasi dan pendidikan mungkin kurang efektif daripada pendekatan yang lebih multi-dimensi. Dalam model hirarki kognitif, pemikiran manusia diatur dari kestabilan, sulit untuk mengubah nilai, perifer dan sikap yang mudah berubah, norma dan perilaku. Dengan demikian, keyakinan dan normanorma lebih rentan terhadap intervensi daripada nilai-nilai dasar (Fulton et al., 1996). Stern dan Dietz (1994) berpendapat bahwa karena mencari informasi dan pengolahan disaring oleh nilai-nilai, orang menerima informasi hanya jika sejalan dengan nilainilai mereka, kesadaran konsekuensi yang merugikan kondisi lingkungan tidak mudah dipengaruhi. Penelitian tentang intervensi telah menunjukkan bahwa kesadaran dan informasi strategi saja mungkin tidak mengakibatkan perubahan perilaku yang diinginkan (Abrahamse et al., 2005; Schultz, 2011). Selain itu, kajian terhadap literatur mengenai praktek pengelolaan sampah mengungkapkan bahwa untuk pengelolaan yang terkait dengan sampah rumah tangga, suatu informasi bukan merupakan prediktor signifikan dari keinginan untuk berpartisipasi pada program pengelolaan sampah rumah tangga. Schultz (2011) berpendapat bahwa keputusan individu untuk terlibat dalam program konservasi lingkungan didorong oleh motivasi dan bukan oleh informasi.

Aktivator norma lainnya telah mendapat peningkatan perhatian dari beberapa ilmuwan. Aktivator seperti anggapan tanggung jawab lokal, norma-norma sosial dan kemampuan telah teridentifikasi untuk menjadi variabel penentu yang lebih menonjol untuk norma personal daripada variabel kesadaran konsekuensi (Pradhananga, 2014; Bamberg dan Moser, 2007; Harland et al., 2007; Steg, Dreijerink, \& Abrahamse, 2005). Menurut NAT, individu merasakan rasa kewajiban personal ketika mereka percaya bahwa mereka memiliki kemampuan untuk mengambil tindakan (Schwartz, 1977). Selanjutnya, kemampuan untuk mengambil tindakan juga merupakan penentu perilaku langsung. Dalam sebuah penelitian meneliti pengaruh variabel NAT pada norma personal dan perilaku, Harland et al. (2007) melaporkan bahwa kemampuan untuk bertindak dipengaruhi niat perilaku untuk menggunakan moda transportasi selain mobil dan untuk menghemat penggunaan energi. Para penulis juga melaporkan bahwa orangorang yang merasa bahwa mereka memiliki kemampuan untuk menjadi sukarelawan juga lebih mungkin untuk menjadi sukarelawan untuk organisasi lingkungan. Schwartz (1977) berpendapat bahwa norma-norma sosial dapat mempengaruhi norma-norma personal dan perilaku, jika mereka digunakan oleh individu sebagai dasar untuk evaluasi diri. Dalam beberapa penelitian, hubungan antara norma subjektif dan niat perilaku telah menjadi lemah (Armitage dan Conner, 2001). Norma subjektif didefinisikan sebagai "tekanan sosial yang dirasakan untuk melakukan atau tidak melakukan perilaku" (Ajzen, 
1991, p.188). Cialdini dan rekan (Cialdini, Kallgren, dan Reno, 1991; Cialdini, Reno, dan Kallgren, 1990) berpendapat bahwa sumber tambahan norma, termasuk norma personal, mempengaruhi hubungan norma-perilaku. Dalam meta-analisis dari faktor-faktor penentu perilaku pro lingkungan, Bamberg dan Moser (2007) menunjukkan pengaruh norma subjektif dalam kaitannya dengan norma personal, menunjukkan bahwa faktorfaktor sosial memainkan peran penting dalam aktivasi norma personal. Dalam penelitian lain penggunaan angkutan umum di antara penduduk dua kota di Jerman, Bamberg et al. (2007) melaporkan pengaruh signifikan dari norma subjektif dari norma personal untuk menggunakan angkutan umum. Model penentuan tindakan komprehensif (Klockner dan Blöbaum, 2010; Klockner, 2013) memberikan dukungan lebih lanjut untuk peran norma subyektif dalam mengaktifkan norma personal. Penelitian ini menunjukkan bahwa seperti yang dikemukakan Schwartz (1977) bahwa norma-norma sosial dapat diinternalisasikan sebagai norma-norma personal.

Pendekatan teoritis perilaku prolingkungan telah diterapkan pada konteks perilaku individu (misalnya, daur ulang, kesediaan untuk membayar pajak lebih besar untuk produk tidak ramah lingkungan). Namun, pendekatan ini belum diterapkan pada perilaku kolektif seperti keterlibatan masyarakat dalam masalah penanganan sampah rumah tangga. Meskipun ada upaya untuk melibatkan warga dalam perencanaan dan manajemen sampah, rumah tangga tidak terlibat dalam masalah pengolahan sampah (Davenport \& Pradhananga, 2012). Memahami motivasi rumah tangga untuk secara aktif terlibat dalam masalah penanganan sampah akan membantu pengurus bank sampah untuk mendesain intervensi keterlibatan masyarakat untuk mempromosikan keterlibatan rumah tangga dalam masalah penanganan sampah melalui bank sampah. Tulisan ini menggunakan sebuah kerangka integratif untuk menguji pengaruh keyakinan dan norma-norma keterlibatan masyarakat dalam isu-isu penanganan sampah rumah tangga.

\section{Model dan Hipotesis Penelitian}

Model konseptual penelitian ini (Gambar 1) mengacu pada Norm Activation Theory (NAT) dan Theory of Planned Behavior (TPB) untuk meneliti faktor-faktor penentu dari perilaku keterlibatan masyarakat yang rentan terhadap perubahan, keyakinan tentang tanggung jawab untuk melindungi lingkungan dari bahaya sampah (anggapan tanggung jawab lokal), melihat kemampuan untuk melindungi lingkungan (kemampuan), harapan sosial penting lainnya (norma subjektif) dan perasaan kewajiban personal untuk secara sukarela terlibat (norma personal). Para peneliti menerapkan teoriteori moral untuk perilaku pro-lingkungan telah menunjukkan bahwa perilaku yang didorong oleh kewajiban personal seseorang untuk bertindak (Stern, 2000).

Selanjutnya, teori ini juga menetapkan bahwa norma-norma personal diaktifkan oleh keyakinan tentang konsekuensi dari kondisi lingkungan, anggapan tanggung jawab untuk aktor yang relevan dan kemampuan mereka sendiri untuk bertindak (Schwartz, 1977; Stern, 2000). Akan tetapi, karena

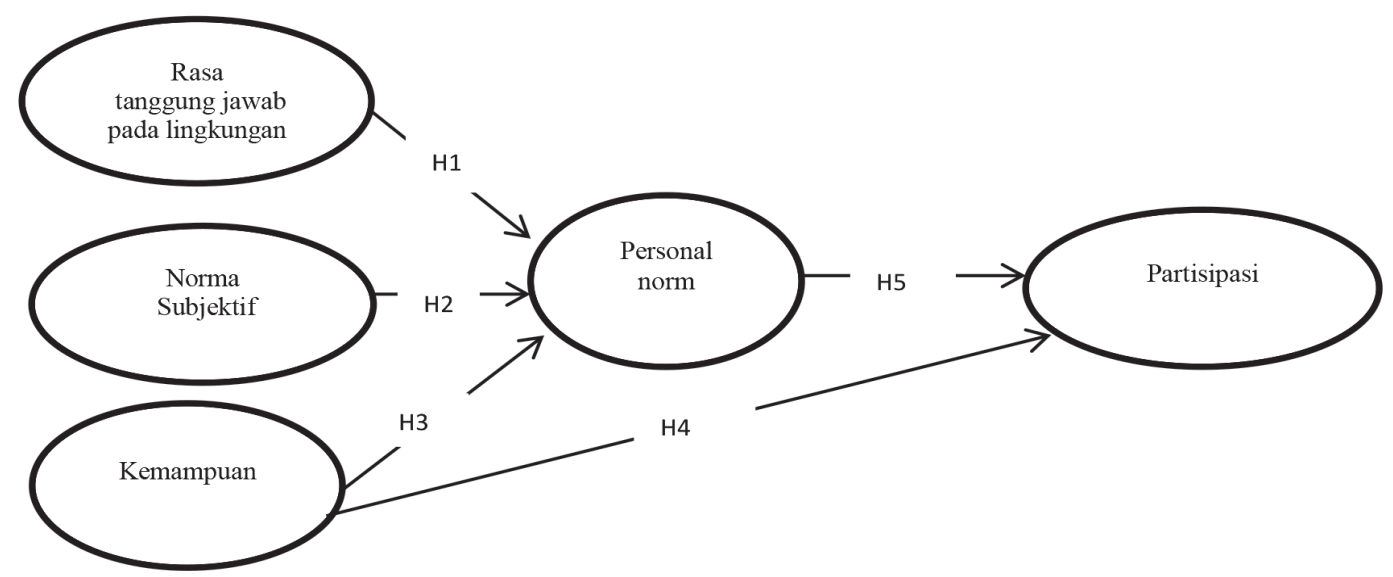

Gambar 1

Model penelitian (Pradananga, 2014) 
individu selektif menerima informasi yang konsisten dengan nilai-nilai mereka (Stern \& Dietz, 1994), keyakinan tentang konsekuensi dari kondisi lingkungan elemen kognitif stabil yang tidak mudah berubah. Dengan demikian, anggapan tanggung jawab dan tidak adanya kesadaran konsekuensi disertakan sebagai penggerak norma personal. Sebagai tambahan, peneliti telah menunjukkan bahwa harapan lain yang penting (norma subjektif) diinternalisasikan sebagai norma personal (Pradhananga, 2014; Bamberg dan Moser, 2007; Klockner, 2013; Schwartz, 1977). Berdasarkan kajian tersebut maka dikembangkan hipotesis:

Hipotesis 1: Anggapan tanggung jawab lokal pada lingkungan akan berpengaruh pada norma personal

Hipotesis 2: Norma subjektif akan berpengaruh pada norma personal

Hipotesis 3: Kemampuan akan berpengaruh pada norma personal

Hipotesis 4: Kemampuan akan berpengaruh pada partisipasi

Hipotesis 5: Norma personal akan berpengaruh pada partisipasi

\section{Metode Desain Penelitian}

Penelitian ini menggunakan pendekatan kuantitatif dengan membangun dan menguji teori serta hipotesis (Cooper dan Schindler, 2008, hlm.165). Desain penelitian yang digunakan dalam penelitian ini yaitu self administered survey dengan unit analisis adalah rumah tangga (bukan keluarga) yang telah terdaftar menjadi nasabah bank sampah di wilayah Kabupaten Banyumas meliputi nasabah bank sampah Sokanegara, bank sampah PAS, Bank sampah Mersi, bank sampah Karangluwas, bank sampah Margasari, bank sampah bintang sembilan, bank sampah Rempoah, bank sampah Satria Mandiri, Bank Sampah KSM Taruna,

Metode penyampelan yang digunakan adalah nonprobablity sampling dengan teknik pengambilan sampel menggunakan purposive sampling yang berasal dari 165 rumah tangga yang berlokasi di sekitar bank sampah dengan kriteria sebagai berikut, (1) telah tercatat menjadi nasabah bank sampah minimal 6 bulan, (2) telah melakukan praktik pemilahan sampah di rumahnya, (3) telah menetap/ tinggal minimal 6 bulan. Kerangka sampling dihasilkan dari pengurus/ pengelola bank sampah. Ukuran sampel yang digunakan adalah minimal 200 dengan mengacu pada pendapat Hair dkk (2010, hlm. 72) bahwa ukuran sampel di atas 200 sudah dapat mengurangi masalah penyimpangan normalitas, sehingga dampak negatif yang ditimbulkan oleh data yang tidak normal dapat diabaikan.

\section{Pengukuran instrumen}

Variabel anggapan tanggung jawab lokal diukur dengan dua item pertanyaan yang diadopsi dari De Groot dan Steg (2009), variabel norma subyektif diukur dengan dua item pertanyaan yang diadopsi dari De Groot dan Steg (2009), variabel kemampuan diukur dengan dua item pertanyaan yang diadopsi dari Pradhananga (2014), Norma personal diukur dengan tiga item pertanyaan. Pertanyaan-pertanyaan yang berkaitan dengan variabel anggapan tanggung jawab, norma subjektif dan kemampuan, responden diminta untuk menilai setiap item pada lima poin skala likert dari sangat tidak setuju (1) sampai sangat setuju (5). Berkaitan dengan variabel partisipasi diukur menggunakan tiga item pertanyaan yang diadopsi dari Fagotto dan Fung (2009).

Khusus untuk variabel partisipasi responden diminta untuk melaporkan berapa kali mereka telah terlibat dalam tiga perilaku partisipasi masyarakat dalam 6 bulan terakhir. Jawaban diberi kode dalam lima poin skala sebagai 0 kali (1), 1 kali (2), 2-4 kali (3), 5-10 kali (4) dan lebih dari 10 kali (5).

\section{Hasil analisis}

Cronbach's alpha digunakan untuk menilai konsistensi internal dari setiap variabel yang diukur dengan lebih dari dua item sedangkan Pearson's correlation digunakan untuk variabel laten yang dikur dengan kurang atau sama dari dua item. Hubungan yang dihipotesiskan dianalisis menggunakan structural equation modeling (SEM). Matrik korelasi dari variabel yang diobservasi digunakan matrik input. Analisis dilakukan menggunakan metode maximum likelihood dengan perangkat lunak LISREL.

Model fit dinilai menggunakan maximum likelihood $x 2$, relative $x 2(x 2 / d f)$, root mean-square error of approximation (RMSEA), comparative fit index (CFI), incremental fit index (IFI), non-normed fit index (NNFI) and standardized root mean square residual (SRMR). Nilai non-significant X2 mengindikasikan bahwa model konsisten dengan data. Makin besar dan nilai nonsignificant values of $\mathrm{x} 2$ mengindikasikan model fit lemah. Namun demikian likelihood X2 maksimum berhubungan secara langsung 
pada ukuran sampel. Oleh karenanya, indeks fit dibutuhkan untuk mengakses model fit. $x 2$ relatif dari 5 atau kurang mengindikasikan model fit yang dapat diterima (Schumacker \& Lomax, 2004). Nilai RMSEA dibahwah 0,10 dapat diterima. RMSEA juga indeks yang sesuai untuk membandingkan model nested. Nilai CFI dan IFI diatas 0,95 direkomendasikan sebagai nilai cut off. Ambang batas dari SRMR $\leq 0,08$ direkomendasikan untuk model fit yang dapat diterima (Hu dan Bentler, 1999).

Ukuran multiple memperbaiki kekayaaan ukuran dari konstruk teoritikal (Maruyuma, 1998). Skala memuat lebih dari 1 (satu) ukuran juga memberikan estimasi konsistensi internal yang lebih baik (Vaske, 2008). Keterbatasan metodologi dari studi ini adalah bahwa 3 (tiga) variabel eksogen (anggapan tanggungjawab, norma subjektif dan kemampuan) diukur dengan hanya 2 (dua) item indikator. Padahal 3 (tiga) atau lebih ukuran konstruk laten direkomendasikan dalam SEM (Kline, 2011). Namun demikian, 2 (dua) ukuran masih diperbolehkan untuk menguraikan sumber yang berbeda dari varian dalam variabel laten SEM. Penelitian sebelumnya berkaitan dengan perilaku proenviromental telah melaporkan model yang handal dalam mengestimasikan menggunakan 2 (dua) item variabel laten SEM (Kaiser et al., 2005). Penelitian dimasa mendatang seharusnya memuat 2 (dua) atau lebih item dengan nilai reliabilitas yang dapat diterima.

\section{Profil Responden}

Dari 250 responden yang disurvei secara langsung, 244 responden mengembalikan kuesioner sehingga tingkat respon (98\%) dan 239 dinyatakan lengkap dan dapat digunakan untuk proses analisis selanjutnya. Sebagian besar responden yang mengisi adalah wanita $212(78 \%)$ sedangkan responden pria $27(22 \%)$. Rata-rata umur responden adalah 45 tahun. Mayoritas rumah tangga beranggotakan lebih dari empat orang (53 $\%$ ) dengan mayoritas tingkat pendidikan terakhir SMP (37\%). Sebagian besar, bapak atau ibu dari rumah tangga adalah petani $(43,1 \%)$ dengan rata-rata pendapatan rumah tangga antara 1.000.000-2.000.000. Secara umum, rumah tangga yang menjadi responden tinggal di perkampungan $(86,2$ $\%)$ dan mayoritas sudah tinggal lebih dari 5 tahun $(45,1 \%)$. Selanjutnya, $76 \%$ dari rumah tangga tersebut tidak memiliki pembantu rumah tangga dan $62,3 \%$ menyatakan bahwa di tempat tinggal mereka terdapat sistem/ fasilitas pengumpulan sampah. Sistem / fasilitas pengolahan sampah yang dimaksud dalam penelitian ini adalah minimal ada jasa angkut didaerah tempat tinggal, yang biasanya dikenakan retribusi per bulan untuk jasa angkut sampah.

Tabel 1

Statistik Deskriptif, analisis reliabilitas and factor loadings

\begin{tabular}{|c|c|c|c|c|c|}
\hline Variabel laten & $\begin{array}{c}\text { Item } \\
\text { pertanyaan }\end{array}$ & Mean & SD & $\begin{array}{c}\text { Standardized } \\
\text { Factor } \\
\text { loadings } \\
(\lambda)\end{array}$ & $\begin{array}{l}\text { Coefficient } \\
\text { alpha (a) }\end{array}$ \\
\hline \multirow{2}{*}{$\begin{array}{l}\text { Anggapan tanggung } \\
\text { jawab }\end{array}$} & TJ1 & 1,57 & 0,63 & 0,77 & \multirow[t]{2}{*}{$0,52^{c}$} \\
\hline & TJ2 & 1,62 & 0,61 & 0,65 & \\
\hline \multirow[t]{2}{*}{ Norma subjektifa } & NS1 & 0,73 & 0,91 & 0,85 & \multirow[t]{2}{*}{$0,67^{c}$} \\
\hline & NS2 & 0,86 & 0,82 & 0,82 & \\
\hline \multirow[t]{2}{*}{ Kemampuan $_{a}$} & KM1 & 0,41 & 1,03 & 0,78 & \multirow[t]{2}{*}{$0,58^{c}$} \\
\hline & KM2 & 0,55 & 0,93 & 0,67 & \\
\hline \multirow[t]{3}{*}{ Norma Personala } & NP1 & 0,70 & 0,74 & 0,86 & \multirow[t]{3}{*}{0,84} \\
\hline & NP2 & 0,49 & 0,82 & 0,82 & \\
\hline & NP3 & 0,53 & 0,83 & 0,79 & \\
\hline \multirow[t]{3}{*}{ Partisipasib } & PS1 & 1,35 & 0,72 & 0,83 & \multirow[t]{3}{*}{0,78} \\
\hline & PS2 & 1,34 & 0,73 & 0,84 & \\
\hline & PS3 & 2,29 & 1,14 & 0,62 & \\
\hline
\end{tabular}

Variabel diukur pada 5 skala poin dari sangat tidak setuju (-2) sampai sangat tidak setuju (2)

${ }^{\mathrm{b}}$ Kode respon : Tidak pernah (1), 1 kali (2) 2-4 kali (3), 5-10 kali (4) dan lebih dari 10 kali (5). 'Bivariate correlations untuk konstruk yang diukur dengan 2 (dua) item ; SD: Standard Deviation 


\section{Uji Validitas dan Reliabilitas}

Pengujian validitas konstruk dengan menggunakan validitas konvergen dengan didasarkan pada nilai factor loading dari setiap item. Hasil pengujian dengan bantuan SPPS diperoleh nilai factor loading pada masingmasing faktor bernilai antara 0,60 sampai 0,85 (Tabel 1), hal ini mengindikasikan bahwa item-item pengukur dari variabel dalam penelitian ini adalah valid. Hair dkk (2010:709) menetapkan factor loading sebesar 0,5 sebagai cutting point.

Hasil pengujian reliabilitas diperoleh nilai bahwa norma personal $(a=0,84)$ and partisipasi masyarakat $(a=0,78)$ sedangkan hasil pengujian menggunakan bivariate correlations dari item pengukur anggapan tanggung jawab $(r=0,52)$, norma subjektif $(r=0,67)$ dan kemampuan $(r=0,58)$, hal ini menunjukan nilai konsistensi internal dari variable-variabel tersebut dapat diterima.

\section{Model struktural}

Model struktural yang memuat anggapan tanggungjawab, norma subjektif dan kemampuan sebagai variabel eksogen and norma personal and partisipasi sebagai variabel endogen menunjukkan model fit yang dapat diterima (Gambar. 2). Nilai chisquare dari model kurang dari $5(\mathrm{x} 2 / \mathrm{df}=$ 1,39). CFI, IFI dan NNFI juga melebih nilai cut off sebesar 0,97. RMSEA dari model dalam batas penerimaan 0,10 (RMSEA: $0,045)$. SRMR dibawah nilai ambang batas $0,08$ (SRMR $=0,047)$. Semua jalur yang dihipotesiskan dalam model penelitian adalah signifikan. Anggapan tanggung jawab berpengaruh secara signifikan pada norma personal $(\beta=0,30)$. Norma subjektif $(\beta=0,27)$. dan kemampuan $(\beta=0,22)$. Norma personal berpengaruh secara signifikan pada keterlibatan masyarakat $(\beta=0,42)$. Selanjutnya, kemampuan juga mempengaruh secara signifikan pada keterlibatan masyarakat $(\beta=0,19)$ (Gambar 2).

\section{Diskusi}

Keyakinan mengenai tanggung jawab lokal untuk melindungi lingkungan, harapan sosial dan kemampuan untuk melindungi lingkungan mengaktivasi norma-norma personal individu untuk berpartisipasi pada program bank sampah. Temuan penelitian ini mendukung proses aktivasi norma yang digariskan dalam NAT. Norma personal untuk mengambil tindakan sipil yang diaktifkan oleh tiga perangkat keyakinan: anggapan tanggung jawab untuk melindungi lingkungan, norma subyektif dan kemampuan untuk melindungi lingkungan. Hasil penelitian menunjukkan bahwa nasabah bank sampah lebih mungkin untuk merasakan kewajiban personal untuk bertindak, jika mereka percaya pada kelestarian lingkungan merupakan tanggung jawab bersama, menganggap bahwa orang lain yang penting mengharapkan mereka untuk melindungi lingkungan, dan percaya bahwa mereka memiliki kemampuan untuk melindungi lingkungan. Hasil penelitian juga mendukung temuan sebelumnya bahwa norma-norma subjektif diinternalisasikan melalui norma personal (Pradhananga, 2014; Bamberg dan Moser, 2007; Klockner, 2013;.

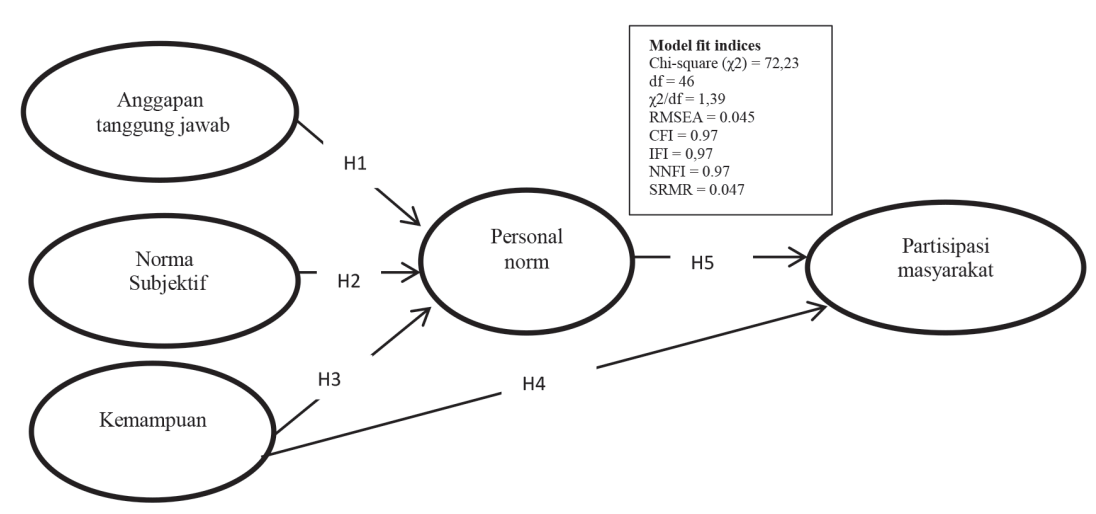

Catatan:

$--\rightarrow$ : Non-significant paths

$\longrightarrow$ : Significant paths $(p \leq 0,05)$

Gambar 2

Model struktural dari of tanggung-jawab, norma subjektif dan norma personal pada partisipasi 
Nigbur et al., 2010). Temuan penelitian ini mengindikasikan bahwa norma subjektif menjadi dasar untuk evaluasi diri, sehingga akan mengaktifkan norma personal individu. Harapan kepada orang lain yang dianggap penting adalah pertimbangan mendasar untuk mengaktifkan harapan diri. Temuan ini menunjukkan bahwa ketika membuat keputusan tentang apakah atau tidak untuk terlibat dalam konservasi secara sukarela, nasabah bank sampah mempertimbangkan apa yang orang penting pikirkan.

Nasabah bank sampah kemungkinan akan terlibat secara sukarela pada program bank sampah, jika mereka merasa memiliki kewajiban personal untuk berpartisipasi dan merasa bahwa mereka memiliki kemampuan untuk berpartisipasi pada bank sampah. Konsisten dengan aplikasi NAT dan VBN sebelumnya (misalnya, Gärling, Fujii, Gärling dan Jakobsson, 2003; Harland, Staats, dan Wilke, 2007; Stern, Dietz, Abel, Guagnano dan Kalof, 1999), norma personal adalah prediksi dari partisipasi masyarakat. Sementara penelitian sebelumnya telah menunjukkan bahwa norma-norma personal mempengaruhi perilaku individu seperti konservasi air (Harland et al., 2007), kesediaan untuk mengurangi penggunaan mobil (Nordlund dan Garvill, 2003), dan daur ulang (Nigbur et al., 2010). Penelitian ini menunjukkan bahwa norma personal juga mendorong rumah tangga untuk berpartisipasi pada bank sampah. Nasabah bank sampah yang merasa kewajiban personal untuk secara sukarela terlibat pada program bank ssampah cenderung untuk mengambil tindakan sukarela seperti menghadiri rapat atau diskusi komunitas tentang penanganan sampah atau bekerja dengan anggota masyarakat untuk melindungi lingkungan.

Temuan penelitian ini mendukung peran kemampuan dalam mengaktifkan norma personal diuraikan dalam NAT, hasil penelitian juga menunjukkan bahwa kemampuan memiliki pengaruh langsung yang signifikan pada partisipasi masyarakat. Dengan demikian, dalam situasi ketika norma-norma personal untuk melindungi lingkungan diaktifkan, nyata atau kurangnya merasakan sumber daya seperti waktu dan keterampilan kemungkinan akan membatasi keterlibatan masyarakat pada program bank sampah. (Lynne et al., 1995) melaporkan pengaruh kemampuan keuangan yang sama pada adopsi teknologi pengolahan sampah (misalnya, teknologi komposting skala rumah tangga). Penelitian ini juga menunjukkan bahwa kemampuan untuk bertindak memiliki pengaruh yang sama pada perilaku kolektif pro-lingkungan seperti keterlibatan masyarakat dalam konservasi lingkungan.

\section{Kontribusi Teoritis}

Beberapa penelitian sebelumnya telah berusaha meneliti aspek sosio-demografis dan geografis sebagai penentu dari partisipasi masyarakat pada program konservasi lingkungan melalui program bank sampah. Penelitian ini berusaha memberikan kerangka teoritis untuk mengeksplorasi faktor-faktor psikososial yang mempengaruhi partisipasi masyarakat dalam program bank sampah. Secara khusus, penelitian ini mengkaji pengaruh norma-norma personal pada partisipasi masyarakat di bank sampah. Temuan penelitian ini selaras dengan penelitian sebelumnya menunjukkan bahwa individu yang secara sukarela untuk terlibat pada program perlindungan lingkungan menunjukkan sikap mendukung dan percaya terhadap program konservasi lingkungan (Larson dan Lach, 2010; Martinez dan McMullin, 2004).

Temuan dari penelitian ini memperluas hubungan antara keyakinan, norma dan keterlibatan masyarakat pada program konservasi lingkungan melalui bank sampah. Model konseptual penelitian ini menawarkan landasan moral untuk memahami partisipasi masyarakat dalam konservasi lingkungan melalui bank sampah. Selain itu, peran dari tiga aktivator: anggapan tanggung jawab, norma subyektif dan kemampuan dalam mengaktivasi norma personal untuk secara sukarela berpartisipasi pada program bank sampah diselidiki. Temuan penelitian ini mengkonfirmasi mengenai efektivitas dari pendekatan moral dalam memahami partisipasi masyarakat pada program konservasi lingkungan. Selanjutnya, penelitian ini juga mendukung temuan sebelumnya yang menemukan adanya hubungan antara normanorma sosial dan personal dan tingkah laku.

\section{Kontribusi Praktis}

Penelitian ini menawarkan landasan teori untuk memahami keterlibatan masyarakat dalam penanganan sampah melalui bank sampah. Meskipun keterlibatan masyarakat dalam pengelolaan sampah rumah tangga semakin diakui oleh para praktisi lingkungan hidup sebagai sesuatu yang penting untuk memecahkan masalah sampah rumah tangga, 
namun penggerak dari perilaku tersebut belum dipahami dengan baik. Hasil penelitian mengungkapkan bahwa rumah tangga yang lebih mungkin terlibat secara sukarela dalam pengelolaan sampah rumah tangga jika mereka merasa secara personal sebagai sesuatu yang tanggung jawab. Temuan penelitian juga menyarankan beberapa strategi untuk untuk mendorong keterlibatan rumah tangga dalam penanganan sampah melalui bank sampah dan perlunya advokasi yang secara terus menerus dalam penelitian mengenai upaya mendorong parsipasi masyarakat pada bank sampah.

Dalam konteks pemasaran sosial, kemitraan dalam pengelolaan bank sampah akan memotivasi partisipasi masyarakat pada bank sampah. Tujuan dari partisipasi masyarakat menekankan pada upaya menghubungkan individu satu dengan individu yang lain untuk terlibat dalam inisiatif pengelolaan sampah melalui bank sampah. Penelitian ini menawarkan beberapa panduan strategis untuk memenuhi tujuantujuan tersebut. Pertama, kombinasi strategi intervensi yang paling efektif, terutama untuk mengatasi kesenjangan keterlibatan masyarakat dimana rumah tangga jauh lebih cenderung melihat konservasi sebagai perhatian individu daripada kolektif (Davenport et al., 2013). Program komunikasi dan pentargetan (targeting) harus menekankan pada perlindungan lingkungan baik sebagai kewajiban moral dan tanggung jawab bersama. Lebih lanjut, program komunikasi dan sosialisasi yang menghadirkan tindakan konservasi, termasuk keterlibatan masyarakat, sebagai norma sosial atau masyarakat cenderung mempengaruhi perilaku individu dalam menangani sampah yang dihasilkan oleh setiap rumah tangga.

Para pengurus bank sampah dan pemasar sosial lainnya telah menyadari bahwa kemampuan yang dirasakan (misalnya, sumber daya, pengetahuan, dan keterampilan) mempengaruhi adopsi praktek pengelolaan rumah tangga. Penelitian ini menunjukkan bahwa kemampuan yang dirasakan berperan penting dalam mendorong perilaku partisipasi masyarakat seperti konservasi dan advokasi lingkungan. Masyarakat yang memiliki pengetahuan, keterampilan dan waktu untuk menggunakan praktek konservasi lingkungan cenderung untuk untuk terlibat pada konservasi lingkungan seperti menghadiri pertemuan yang mendiskusikan isu-isu lingkungan, terlibat dengan anggota masyarakat lain dalam konservasi lingkungan dan berbicara dengan orang lain tentang praktek konservasi. Dengan demikian, terlihat jelas adanya peluang untuk lebih mengembangkan program bank sampah melalui peningkatan keterampilan para pemasar sosial dalam berkomunikasi dengan masayarakat, kepemimpinan dan pengorganisasian masyarakat. Temuan ini juga menunjukkan adanya kebutuhan yang sedang berlangsung untuk mengatasi hambatan dan kendala kemampuan yang dirasakan dan memberikan dukungan untuk komunikasi dan penjangkauan program yang meningkatkan pengetahuan dan keterampilan nasabah bank sampah tentang pengelolaan sampah. Kementrian lingkungan hidup telah menawarkan adanya program bank sampah berbasis warga sebagai pendekatan lain untuk meningkatkan keterlibatan masyarakat dalam penanganan sampah. Tantangan lain yang dihadapi para pemasar sosial dalam memasakan bank sampah adalah bagaimana menumbuhkan minat dan dukungan masyarakat pada program bank sampah. Temuan penelitian menunjukkan bahwa para pemimpin masyarakat cenderung memiliki kelompok sosial rujukan yang menekan mereka untuk menggunakan praktek pengelolaan sampah melalui bank sampah. Selanjutnya temuan penelitian menunjukkan bahwa responden yang merasakan tekanan sosial terbesar untuk berpartisipasi pada bank sampah dipengaruhi oleh anggota keluarga, tetangga, organisasi advokasi lingkungan, pemerintah daerah dan para peneliti universitas. Dengan kata lain, ada berbagai kelompok sosial dan organisasi yang memiliki pengaruh pada pengambilan keputusan untuk terlibat pada penanganan sampah rumah tangga melalui bank sampah. Kelompok-kelompok ini harus mempromosikan kepedulian lingkungan sebagai sebuah norma sosial dan tanggung jawab bersama.

\section{Penelitian di Masa Depan}

Dari sudut pandang teoritis, dimungkinkan faktor-faktor tambahan yang mengaktifkan norma personal atau secara langsung dapat mempengaruhi perilaku. Pendekatan identitas sosial berpendapat bahwa perilaku juga didorong oleh sejauh mana individu mengidentifikasi dengan kelompok mereka. Ketika individu mengidentifikasi kuat dengan kelompok mereka, norma kelompok akan mempengaruhi perilaku (Terry \& Hogg, 1996; . White et al., 2009). Teori identitas Stryker (Stryker dan Burke, 2000; Stryker, 1987) berpendapat bahwa individu 
bertindak sesuai dengan identitas diri mereka. Identitas diri sebagai aktivis lingkungan adalah prediktor yang kuat dari niat untuk terlibat dalam aktivitas pro lingkungan bagi mereka yang identik dengan kelompokkelompok lingkungan (Fielding, McDonald, dan Louis, 2008). Penelitian di masa depan harus mengeksplorasi peran identifikasi sosial individu dengan masyarakat dan identitas diri mereka sebagai warga negara untuk menjelaskan perilaku keterlibatan masyarakat pada gerakan kepedulian lingkungan. Sebuah konsep alternatif norma sosial: norma deskriptif, atau perilaku orang lain, juga telah diusulkan sebagai faktor yang mempengaruhi niat perilaku. Penelitian ini menunjukkan bahwa individu akan menyesuaikan norma deskriptifnya dengan meniru perilaku orang lain (Nigbur et al., 2010; White et al., 2009). Demikian melihat anggota masyarakat lainnya berpartisipasi pada pada bank sampah akan memacu individu untuk secara sukarela untuk ikut berpartisipasi pada bank sampah. Hubungan antara norma deskriptif dan perilaku, dan perannya dalam mengaktifkan norma personal harus dieksplorasi dalam penelitian masa depan.

\section{Simpulan dan Saran}

Temuan penelitian menunjukkan bahwa keterlibatan masyarakat pada penanganan sampah rumha tangga melalui bank sampah didorong oleh pertimbangan moral. Ketika pemilik tanah merasa kewajiban moral untuk terlibat secara suka rela, mereka lebih cenderung untuk terlibat dengan orang lain dalam tindakan konservasi lingkungan. Seperti yang dikemukakan oleh Schwartz (1977), hasil penelitian menunjukkan bahwa norma personal yang diaktifkan oleh struktur keyakinan kognitif termasuk merasakan tanggung jawab lokal untuk perlindungan sumber daya air, norma subjektif untuk tindakan konservasi dan kemampuan untuk melindungi sumber daya air di properti personal seseorang. Yang penting adalah, temuan penelitian juga menetapkan normanorma subjektif sebagai tambahan yang berguna untuk pendekatan moral yang model teoritis seperti NAT dan VBN. Apa yang orang lain pikirkan adalah penentu signifikan dari keterlibatan masyarakat dalam program penanganan sampah rumah tangga melalui bank sampah.

\section{Ucapan Terimakasih}

Penelitian ini mendapat dukungan pendanaan Direktorat Jenderal Perguruan Tinggi Kementrian
Pendidikan dan Kebudayaan, Republik Indonesia melalui Skim Hibah Bersaing tahun anggaran 2014.

\section{Daftar Pustaka}

Abrahamse, W., Steg, L., Vlek, C., \& Rothengatter, T. (2005). A review of intervention studies aimed at household energy conservation. Journal of Environmental Psychology, 25(3), 273291.

Ajzen, I., \& Fishbein, M. (1980). Understanding attitudes and predicting social behavior. Englewood Cliffs, NJ: Prentice-Hall, Inc.

Ajzen, I., 1991. The theory of planned behavior. Organizational Behavior and Human Decision Processes 50, 179-211.

Ajzen, I., Fishbein, M., 1980. Understanding attitudes and predicting social behavior. Prentice Hall, Englewood Cliffs, NJ.

Armitage, C. J., \& Conner, M. (2001). Efficacy of the theory of planned behaviour: A meta analytic review. British Journal of Social Psychology, 40(4), 471-499.

Armstrong, S. (2014). Continuing Necessity of Common Law Torts for Environmental Harms: Why the Clean Air Act Should Not Preempt State Law Claims against Stationary Sources, The. Tex. Environtal. $L J, 44,391$.

Armstrong, A., \& Stedman, R. C. (2012). Landowner willingness to implement riparian buffers in a transitioning watershed. Landscape and Urban Planning. Retrieved from

Bamberg, S., \& Möser, G. (2007). Twenty years after Hines, Hungerford, and Tomera: A new meta-analysis of psychosocial determinants of pro-environmental behaviour. Journal of Environmental Psychology, 27(1), 14-25. doi:10.1016/j. jenvp.2006.12.002

Bamberg, S., Hunecke, M., \& Blöbaum, A. (2007). Social context, personal norms and the use of public transportation: Two field studies. Journal of Environmental Psychology, 27(3), 190-203. doi:10.1016/j.jenvp.2007.04.001

Brooks, J. S., Franzen, M. A., Holmes, C. M., Grote, M. N., \& Mulder, M. B. (2006). Testing hypotheses for the success of different conservation strategies. Conservation Biology, 20 (5), 1528-1538.

Cialdini, R. B., Kallgren, C. A., \& Reno, R. R. (1991). A focus theory of normative conduct: A theoretical refinement and reevaluation of the role of norms in human behavior. Advances in Experimental Social 
Psychology, 24(20), 1-243.

Cialdini, R. B., Reno, R. R., \& Kallgren, C. A. (1990). A focus theory of normative conduct: Recycling the concept of norms to reduce littering in public places. Journal of Personality and Social Psychology, 58(6), 1015.

Cooper, D.R dan P.S. Schindler. (2008), Business Research Methods, 10 th ed, New York, NY: Mc. Graw-Hill/Irwin.

Davenport, M., \& Pradhananga, A. (2012). Perspectives on Minnesota Water Resources: A Survey of Sand Creek and Vermillion River Watershed Landowners. Department of Forest Resources, University of Minnesota. Retrieved from http://www. forestry.umn.edu/prod/groups/cfans/@ pub/@cfans/@forestry/docume nts/asset/ cfans_asset_379379.pdf

Davenport, M., Pradhananga, A., \& Nelson, P. (2013). Increasing voluntary conservation practice adoption through research and relationship building. Water Resources Impact, 15(2), 9-12.

Dawes, R. M. (1980). Social dilemmas. Annual Review of Psychology, 31(1), 169-193.

Dawes, R. M., \& Messick, D. M. (2000). Social dilemmas. International Journal of Psychology, 35(2), 111-116.

De Groot, J. I., \& Steg, L. (2009). Morality and prosocial behavior: The role of awareness, responsibility, and norms in the Norm Activation Model. The Journal of Social Psychology, 149(4), 425-449.

Dietz, T., Stern, P. C., \& Guagnano, G. A. (1998). Social Structural and Social Psychological Bases of Environmental Concern. Environment and Behavior, 30(4), 450471. doi: $10.1177 / 001391659803000402$

Environmental Science and Technology 42, 1509-1630. Miller, G.T., 2000. Living in the Environment: Principles, Connections, and Solutions, 13th ed. Brooks Cole, Belmont, CA.

Fagotto, E., \& Fung, A. (2009). Sustaining public engagement: Embedded deliberation in local communities. East Hartford, CT: Everyday Democracy \& Kettering Foundation.

Fielding, K. S., McDonald, R., \& Louis, W. R. (2008). Theory of planned behaviour, identity and intentions to engage in environmental activism. Journal of Environmental Psychology, 28(4), 318326.

Fulton, D. C., Manfredo, M. J., \& Lipscomb, J. (1996). Wildlife value orientations: A conceptual and measurement approach. Human Dimensions of Wildlife, 1(2), 24-
47.

Gärling, T., Fujii, S., Gärling, A., \& Jakobsson, C. (2003). Moderating effects of social value orientation on determinants of proenvironmental behavior intention. Journal of Environmental Psychology, 23(1), 1-9.

Hair, J.F; W.C. Black; B.J Babin; R.E. Anderson; dan R.L Tatham (2010), Multivariate Data Analysis, $7^{\text {th }}$ ed Upper Saddler River, NJ: Person Education, Inc

Harland, P., Staats, H., \& Wilke, H. A. M. (2007). Situational and personality factors as direct or personal norm mediated predictors of pro-environmental behavior: Questions derived from normactivation theory. Basic and Applied Social Psychology, 29(4), 323-334.

Johansson, M., Rahm, J., \& Gyllin, M. (2013). Landowners' Participation in Biodiversity Conservation Examined through the Value-Belief-Norm Theory. Landscape Research, 38(3), 295-311.

Kaiser, F. G., Hübner, G., \& Bogner, F. X. (2005). Contrasting the Theory of Planned Behavior With the Value-Belief-Norm Model in Explaining Conservation Behavior. Journal of Applied Social Psychology, 35(10), 2150-2170.

Kallgren, C. A., Reno, R. R., \& Cialdini, R. B. (2000). A focus theory of normative conduct: When norms do and do not affect behavior. Personality and Social Psychology Bulletin, 26(8), 1002-1012.

Karak, T., Bhagat, R.M., Bhattacharyya, P., (2012). Municipal solid waste generation, composition, and management: The world scenario. Critical Reviews in

Kline, R. B. (2011). Principles and Practice of Structural Equation Modeling, Third Edition. Guilford Press.

Klöckner, C. A. (2013b). A comprehensive model of the psychology of environmental behaviour-A meta-analysis. Global Environmental Change, 23(5), 10281038.

Klöckner, C. A., \& Blöbaum, A. (2010). A comprehensive action determination model: Toward a broader understanding of ecological behaviour using the example of travel mode choice. Journal of Environmental Psychology, 30(4), 574-586.

Knowler, D., \& Bradshaw, B. (2007). Farmers' adoption of conservation agriculture: A review and synthesis of recent research. Food Policy, 32, 25-48.

Koehler, B., \& Koontz, T. M. (2008). Citizen participation in collaborative watershed 
partnerships. Environmental Management, 41(2), 143-154.

Kofoworola, O.F., 2007. Recovery and recycling practices in municipal solid waste management in Lagos. Nigeria. Waste Management 27 (9), 1139-1143.

Larson, K. L., \& Lach, D. (2010). Equity in urban water governance through participatory, place-based approaches. Nat. Resources J., 50, 407.

Lehman, Philip K. dan E.Scott Geller. (2004), Behavior Analysis and Environment Protection: Accomplishment and Potential For More, "Behavior and Social Science, Vol.13, No.1, Hal.13-32

Lynne, G. D., Franklin Casey, C., Hodges, A., \& Rahmani, M. (1995). Conservation technology adoption decisions and the theory of planned behavior. Journal of Economic Psychology, 16(4), 581-598.

Mahar, A., Malik, R. N., Qadir, A., Ahmed, T., Khan, Z., \& Khan, M. A. (2007, September). Review and analysis of current solid waste management situation in urban areas of Pakistan. In Proceedings of the International Conference on Sustainable Solid Waste Management. Chennai (pp. 34-41).

Manzo, L. C., \& Weinstein, N. D. (1987). Behavioral Commitment to Environmental Protection A Study of Active and Nonactive Members of the Sierra Club. Environment and Behavior, 19(6), 673-694.

Martinez, T. A., \& McMullin, S. L. (2004). Factors Affecting Decisions to Volunteer in Nongovernmental Organizations. Environment and Behavior, 36(1), 112126. doi: $10.1177 / 0013916503256642$

Mbande, C., (2003). Appropriate approach in measuring waste generation, composition and density in developing areas. Journal of the South African Institution of Civil Engineering 45, 2-10.

Miller, W., Alexander, R., Chapman, N., McKinley, J. C., \& Smellie, J. A. T. (Eds.). (2000). Geological disposal of radioactive wastes and natural analogues, Vol.2.

Nigbur, D., Lyons, E., \& Uzzell, D. (2010). Attitudes, norms, identity and environmental behaviour: Using an expanded theory of planned behaviour to predict participation in a kerbside recycling programme. British Journal of Social Psychology, 49(2), 259-284.

Nordlund, A. M., \& Garvill, J. (2003). Effects of values, problem awareness, and personal norm on willingness to reduce personal car use. Journal of Environmental

Pradhananga. (2014). A moral obligation model of landowner conservation norms and behavior, Desertation, University Of Minnesota.

Rahardyan, B., Matsuto, T., Kakuta, Y., Tanaka, N., (2004). Resident's concerns and attitudes towards Solid Waste Management facilities. Waste Management 24 (5), 437-451.

Samsudin, M. D. M., \& Don, M. M. (2013). Municipal Solid Waste Management in Malaysia: Current Practices, Challenges and Prospects. Jurnal Teknologi, 62(1).

Schultz, P. (2011). Conservation means behavior. Conservation Biology, 25(6), 1080- 1083.

Schumacker, R. E., \& Lomax, R. G. (2004). A beginner's guide to structural equation modeling (Vol. 1). Lawrence Erlbaum.

Schwartz, S. H. (1970). Moral decision making and behavior. Altruism and Helping Behavior, 127-141.

Schwartz, S. H. (1977). Normative Influences on Altruism1. Advances in Experimental Social Psychology, 10, 221-279.

Schwartz, S. H. (1994). Are there Universal Aspects in the Structure and Contents of Human Values? Journal of Social Issues, 50(4), 19-45.

Smith, D. H. (1994). Determinants of voluntary association participation and volunteering: A literature review. Nonprofit and Voluntary Sector Quarterly, 23(3), 243-263.

Soule, M. J., Tegene, A., \& Wiebe, K. D. (2000). Land tenure and the adoption of conservation practices. American Journal of Agricultural Economics, 82(4), 9931005.

Steg, L., \& Vlek, C. (2009). Encouraging proenvironmental behaviour: An integrative review and research agenda. Journal of Environmental Psychology, 29(3), 309317.

Steg, L., Dreijerink, L., \& Abrahamse, W. (2005). Factors influencing the acceptability of energy policies: A test of VBN theory. Journal of Environmental Psychology, 25(4), 415 -425.

Stern, P. C. (1999). Information, incentives, and proenvironmental consumer behavior. Journal of Consumer Policy, 22(4), 461-478.

Stern, P. C. (2000). New environmental theories: Toward a coherent theory of environmentally significant behavior. Journal of Social Issues, 56(3), 407-424.

Stern, P. C., \& Dietz, T. (1994). The value basis of environmental concern. Journal of Social Issues, 50(3), 65-84. 
Stern, P. C., Dietz, T., \& Black, J. S. (1986). Support for environmental protection: The role of moral norms. Population \& Environment, 8(3), 204-222.

Stern, P. C., Dietz, T., \& Guagnano, G. A. (1995). The new ecological paradigm in social-psychological context. Environment and Behavior, 27(6), 723-743.

Stern, P. C., Dietz, T., Abel, T., Guagnano, G. A., \& Kalof, L. (1999). A value-beliefnorm theory of support for social movements: The case of environmentalism. Human Ecology Review, 6(2), 81-98.

Story, P. A., \& Forsyth, D. R. (2008). Watershed conservation and preservation: Environmental engagement as helping behavior. Journal of Environmental Psychology, 28(4), 305-317.

Stryker, S. (1987). Identity theory: developments and extensions. Retrieved from http://psycnet.apa.org/ psycinfo/1987-97316-006

Stryker, S., \& Burke, P. J. (2000). The past, present, and future of an identity theory. Social Psychology Quarterly. Retrieved from http://psycnet.apa.org/ psycinfo/2001-10002-001

Terry, D. J., \& Hogg, M. A. (1996). Group norms and the attitude-behavior relationship: A role for group identification. Personality and Social Psychology Bulletin, 22(8), 776-793.

Thøgersen, J. (1996). Recycling and Morality A Critical Review of the Literature. Environment and Behavior, 28(4), 536558.

Van Liere, K.D., Dunlap, R.E., 1978. Moral norms and environmental behavior: An application of Schwartz's norm-activation model to yard burning. Journal of Applied Social Psychology 8, 174-188.

Vaske, J. J. (2008). Survey Research and Analysis: Applications in Parks, Recreation and Human Dimensions. Venture Pub. Vermillion River Corridor Plan. (2010). Retrieved from http:// www. vermillionriverwatershed.org/ attachments/058_Vermillion\%20Corrid or\%20Plan\%200ctober\%202010.pdf

White, K. M., Smith, J. R., Terry, D. J., Greenslade, J. H., \& McKimmie, B. M. (2009). Social influence in the theory of planned behaviour: The role of descriptive, injunctive, and in-group norms. British Journal of Social Psychology, 48(1), 135158.

Wilkinson, N., (2007). An Introduction to Behavioral Economics. Palgrave Macmillan, London, UK. 